Vol. 14, $n^{\circ} 1 \mid 2010$

Varia

\title{
Police 'Outrages' against British Residents and Travellers in Liberal Italy, 1867-1877
}

\section{O.J. Wright}

\section{(2) OpenEdition \\ 1 Journals}

\section{Electronic version}

URL: https://journals.openedition.org/chs/1143

DOI: 10.4000/chs. 1143

ISSN: 1663-4837

Publisher

Librairie Droz

\section{Printed version}

Date of publication: 1 May 2010

Number of pages: $51-72$

ISBN: 978-2-600-01425-0

ISSN: $1422-0857$

\section{Electronic reference}

O.J. Wright, "Police 'Outrages' against British Residents and Travellers in Liberal Italy, 1867-1877", Crime, Histoire \& Sociétés / Crime, History \& Societies [Online], Vol. 14, $n^{\circ} 1$ | 2010, Online since 01 May 2013, connection on 25 March 2022. URL: http://journals.openedition.org/chs/1143 ; DOI: https:// doi.org/10.4000/chs. 1143 


\title{
Police 'Outrages' against British Residents and Travellers in Liberal Italy, 1867-1877
}

\author{
O.J. Wright ${ }^{1}$
}

\begin{abstract}
On a beaucoup écrit sur les relations politiques et culturelles entre la Grande-Bretagne et l'Italie d'avant l'unification, mais on n'a guère prêté d'attention à l'Italie libérale, c'est-à-dire le royaume unifié qui émergea du Risorgimento en 1861. Cet article examine un certain nombre d'incidents qui impliquèrent des résidents ou voyageurs britanniques plus ou moins innocents dans ce pays entre 1867 et 1877. Dans la plupart de ces cas, des citoyens britanniques furent détenus par les Carabinieri, force de police militarisée italienne, en raison de leur incapacité à - ou de leur refus de - faire la preuve de leur identité. Bien que les sujets britanniques ne fussent pas tenus d'avoir sur eux un passeport en Italie, chacun, y compris les Italiens, était supposé disposer d'un document d'identité quelconque. La plupart des Britanniques concernés ignoraient cette règle, et beaucoup d'entre eux aggravèrent leurs difficultés par un comportement d'obstruction ou de provocation. Ces épisodes suscitèrent des tensions considérables entre les gouvernements des deux pays, dont les relations étaient par ailleurs amicales. Cette étude montre que les nationaux britanniques ne pouvaient pas réclamer d'indemnisation au gouvernement italien, même s'ils alléguaient de mauvais traitements de la part de ses agents. Ses résultats corroborent aussi la théorie selon laquelle la notion victorienne de supériorité étaient largement fondée sur des «valeurs», en l'occurrence, une croyance fervente dans la liberté d'aller et venir sans entraves ou sans surveillance intrusive de la part des autorités. Enfin, l'étude confirme l'idée que les Victoriens n'étaient pas habitués au port de documents d'identité et étaient très mécontents d'avoir à s'y soumettre.
\end{abstract}

Much has been written about British political and cultural relations with Italy before the country's unification, while little attention has been paid to Liberal Italy, the unified kingdom which emerged from the Risorgimento in 1861. This article examines a number of incidents which involved innocent

\footnotetext{
O.J. Wright has taught modern history at Lancaster and Kingston Universities, and is now a sessional lecturer at the University of Worcester. His research focuses mainly on British political and cultural relations with Liberal Italy, but he has a particular interest in the modern history of the island of Sardinia. His most recent publications are: Wright, O.J., The 'Pleasantest Post' in the Service? Contrasting British Diplomatic and Consular Experiences in Early Liberal Italy, in Schaff, B. (ed.), Exiles, Émigrés and Go-Betweens: Anglo-Italian Cultural Mediation, Amsterdam \& New York, 2009; British Representatives and the Surveillance of Italian Affairs (1860-1870), The Historical Journal, Autumn 2008, 51, 3, pp. 669-687; Sea and Sardinia: Pax Britannica versus Vendetta in the New Italy (1870), European History Quarterly, Summer 2007, 37, 3, pp. 398-416.
} 
and not-so-innocent British residents and travellers in the country between 1867 and 1877. In most of these cases British nationals were detained by the Carabinieri, Italy's militarized police force, for being unable or for refusing to provide evidence of their identity. Although British subjects were not required to carry passports in Italy, all persons - including Italians - were expected to be in possession of some form of identity document. The Britons concerned were in almost every case unaware of this regulation, and many of them exacerbated their predicament through obstructive or provocative behaviour. These episodes caused considerable aggravation between the governments of the two countries, creating friction in an otherwise amicable relationship. This study reveals that British nationals could not claim compensation from the Italian government even if they were deemed to have been mistreated by its agents. Its findings are also consistent with the theory that Victorian notions of supremacy were based very much upon 'values'; in this case, a fervent belief in the right of private individuals to go about their legitimate business free from encumbrance or intrusive surveillance by the authorities. Finally, besides confirming the suggestion that the Victorians were unaccustomed to carrying identity documents about their person, this examination shows that they felt considerable resentment at having to do so.

$\mathrm{I}^{\mathrm{n}}$ 1867 a British national was arrested by the Italian Carabinieri in Tuscany and detained for a fortnight without access to diplomatic or consular representation. It was on account of Alexander Cruickshank's 'suspicious appearance and demeanour' that he had been approached at Grosseto railway station in Tuscany. When asked to identify himself Cruickshank had failed to produce documentary evidence of his identity, and claimed to have arrived by train from Marseille via a route which did not yet exist. By the time his case reached the attention of Edward Herries, the British chargé d'affaires in Italy, it had emerged that Cruickshank was a priest who spoke good Italian and had long been resident in the country. Herries accepted that Cruickshank had contributed to his own misfortune through his blatant dishonesty, and concluded that he had been travelling 'with no good intentions'. Nonetheless, in a manner quite typical of British relations with the Kingdom of Italy, the diplomat issued a haughty rebuke, asserting that 'mere suspicion could not warrant ... detention in prison for a fortnight' ${ }^{2}$. The Italians did not defend the conduct of the officers concerned but, with Giuseppe Garibaldi preparing an expedition to invade the independent Papal State of Rome, they explained that extraordinary vigilance was necessary. Within months, and amid the upheaval caused by Garibaldi's expedition, a British woman named Mrs Stone was arrested while helping a French priest convey wounded soldiers to safety. The newly-appointed British envoy to Italy, Sir Augustus Paget, was appalled. Paget protested that a lady and a priest who held valid passports and were performing 'a work of humanity' could hardly appear

For comments and observations which have been useful in the preparation of this article, I would like to thank the Journal's two anonymous reviewers as well as delegates of the Conference on Modern British History (University of Strathclyde, 2008). I would also like to thank Lord Clarendon for permission to quote from the Clarendon Papers.

2 The National Archives (hereafter TNA), FO 45/106, Herries to Stanley, 31 July 1867.

3 TNA, FO 45/108, Paget to Stanley, 4 November 1867, and Paget to Campello, 24 October 1867 , copy enclosed in the former. 
'formidable or dangerous characters', and hoped that steps would be taken 'to prevent peaceable British subjects from being molested in future' ${ }^{3}$. Unfortunately, the arrests of Cruickshank and Stone were the first of a succession of occurrences which would mar Paget's otherwise happy tenure of the British diplomatic mission to Italy ${ }^{4}$.

Upon his release Cruickshank had made a poignant declaration: 'They talk or did talk about the prisons of Naples under the late [Bourbon] King, but the free Kingdom of Italy is quite as bad' ${ }^{5}$. Cruickshank's words reflected a considerable British disillusionment with the reality of Liberal Italy. In 1860 the British government headed by Viscount Palmerston, Lord John Russell, and William Gladstone had welcomed the Unification of Italy as though it were a repeat of the Glorious Revolution of $1688^{6}$. Official approval was surpassed by wild public enthusiasm, the extent of which was fully exposed when Garibaldi visited London in 1864'. Although Garibaldi's rapturous reception owed much to his personal popularity ${ }^{8}$, the creation of a unified and constitutional Italian kingdom appealed to Victorian sympathies. The British had come to maintain a conspicuous presence in Italy, having initially been drawn by its commercial opportunities ${ }^{9}$, before becoming fascinated by its Roman and Renaissance heritage ${ }^{10}$. However, British visitors were frequently disparaging of the country's modern inhabitants, and were often horrified at their living conditions ${ }^{11}$. The idea that modern Italy's degradation resulted from its misgovernment became widespread after Gladstone's famous visit to Naples in $1851^{12}$, and was compounded by a number of cases of religious repression involving Britons in Tuscany ${ }^{13}$. The exile in England of several prominent Italians, most notably Giuseppe Mazzini, Antonio Panizzi, and Giacomo Lacaita, served further to publicize the Italian national cause ${ }^{14}$. Many Victorians were convinced that their own civilization, with its parliamentary monarchy, free trade and civil liberties, represented the pinnacle of human achievement ${ }^{15}$. Many were eager to see Italy reconstructed along similar lines ${ }^{16}$. Far from providing a vindication of the Victorian polity,

4 Paget was appointed Envoy Extraordinary and First Minister Plenipotentiary to Italy in 1867; his position was upgraded to that of Ambassador to Italy in 1876, and he left the country with extreme reluctance when transferred to Vienna in 1883. See Wright (2009).

5 TNA, FO 45/106, Cruickshank to Macbean, 18 July 1867, copy enclosed in Herries to Stanley, 31 July 1867.

6 Russell to Hudson, 27 October 1860, in Selections from Speeches of Earl Russell 1817 to 1841 and from Despatches 1859 to 1865 (London, 1870), Vol. II, pp. 328-332. See also Beales (1961); Bourne (1970, pp. 102-105); Hoppen (1998, pp. 227-230); Taylor (1954, p. 124).

7 See Beales (1991).

8 See Riall (2007).

9 Bradford (2000, p. 443); Procacci (1970, p. 150).

10 For good recent studies, see: Chaney (2000); Black (2003a); Pemble (1987).

11 Brand (1957, pp. 196-200).

12 See Gladstone (1851); Gopal (1956); Schreuder (1970).

13 See Correspondence relating to Case of Count Guicciardini, Parliamentary Papers (hereafter BPP), 1854 LXXII 809; Correspondence respecting the Case of Francesco and Rosa Madiai, 1851-1853, BPP, 1852-53 CII 633; Correspondence relating to the recent Case of the Imprisonment of Miss Cunninghame at Florence, BPP, 1854-55 LV 303.

14 Mack Smith (1994, pp. 20-31; 89-96); Brooks (1931); Lacaita (1933).

15 James (1998, p. 165).

16 O'Connor (1998). 
however, Italy experienced a very difficult transition from fragmentation to unity, and its new leaders lost much British sympathy.

A great deal has been written about the British political and cultural relationships with Italy prior to its unification ${ }^{17}$. By contrast, little attention has been paid to the following period ${ }^{18}$. This article improves our understanding of Britain's much overlooked relationship with Liberal Italy. It does so by focusing on the succession of incidents which involved innocent and not-so-innocent British residents and travellers in the country during the decade between 1867 and 1877. In most of these cases British nationals were detained by the Carabinieri, Italy's militarized police force, for being unable or for refusing to provide evidence of their identity. Although British subjects were not required to carry passports in Italy, all persons - including Italians - were expected to be in possession of some form of identity document. The Britons concerned were in almost every case ignorant of this regulation, and many of them exacerbated their predicament through obstructive or provocative behaviour. Religious identity appears to have been a factor linking some of these occurrences, as does a strain of anti-British sentiment within the Carabinieri; one individual even seems to have been the target of a vendetta perpetrated by Sicilian officials. These episodes were a cause of considerable aggravation which tarnished the otherwise amicable relationship between the British and Italian governments. The fact that they occurred at all is illustrative of the mentality of the Victorians abroad, a significant number of whom were content to travel to Italy in ignorance of its regulations and without sufficient respect for its officers or institutions. The British reactions to these events indicate that the British government, diplomats, and press considered Liberal Italy to have retained too many of the illiberal characteristics of its predecessor states. It is also apparent that they failed to understand the scale and complexity of the challenges faced by the newly-unified Italian kingdom. British nationals who were the victims of crimes such as theft or kidnapping in Italy could not expect compensation from the Italian government ${ }^{19}$; nor could they expect it for mistreatment by the Italian authorities, as this study reveals. The findings of this research are consistent with the theory that Victorian notions of supremacy were based very much upon 'values ${ }^{20}$; in this case, a fervent belief in the right of private individuals to go about their legitimate business free from encumbrance or intrusive surveillance by the authorities. Finally, besides confirming the suggestion that the Victorians were unaccustomed to carrying identity documents about their person, this examination shows that they felt considerable resentment at having to do $\mathrm{so}^{21}$.

Several years after the arrests of Cruickshank and Stone, three separate events drew British attention to policing in Liberal Italy. In 1872 William Mercer boarded a ferry at Portocariello near Naples on the understanding that the fare was half a franc. Upon disembarking the boatmen tried to charge him a whole franc, whereupon his refusal to pay attracted a passing carabiniere. When the officer insisted that the Englishman pay the boatmen the whole sum, Mercer responded foolishly by

17 For political relations, see Taylor (1934); Tedeschi (1978); Carter (1993, 1997). For cultural relations, see Brand (1957); O'Connor (1998); Cavaliero (2005); Rudman (1940).

18 For rare examples, see De Leonardis (1980); Priestley (1931); Wright (2005; 2008).

19 Blinkhorn (2000).

20 For this theme more generally, see Black (1994, pp. 196-197).

21 See also Agar (2001); Fahrmeir (2001). 
accusing him of being involved in the scam. He was placed under arrest, but resisted. The boatmen and harbourmaster intervened to subdue him, and he was put in what he described as 'thumbscrews'. Mercer was then imprisoned at Castellamare, before being released on the charge of 'committing gross abuse and violence towards the agents of the public force'. The case proceeded to court and resulted in Mercer's complete acquittal, prompting the legal advisor to the British Legation to suggest that he was entitled to sue the Italian government for compensation ${ }^{22}$. In 1873, while Mercer was still awaiting trial, Arthur Vansittart was one of a group of Catholics attacked by an anticlerical mob in Rome. He suffered a gash to the head and a swollen forearm, and accused the municipal police of not intervening to help until the crowd had dispersed ${ }^{23}$. Several men were arrested and tried, including Vansittart, but all were acquitted. A number of British residents complained about the police and petitioned for an inquiry into the incident ${ }^{24}$; some later admitted to having been coerced into signing, and one even spoke in defence of the police ${ }^{25}$. The subsequent investigation cleared the authorities of any blame and alleged that the victims had provoked their attackers by staring at them 'in a provocative manner' ${ }^{26}$. At his trial Vansittart had even been revealed as having provoked his assailants by calling them 'vile Italians' ${ }^{27}$. Within weeks of Vansittart's attack another Briton, a Dr Dempster, was involved in a fracas with a municipal guard in Naples. The officer had arrested one man when a second stepped in to help the prisoner escape. A scuffle ensued, and Dempster was so horrified by the aggression of the guard that he intervened, grabbing the policeman's sword and enabling both men to flee. Not surprisingly, Dempster then found himself under arrest until an influential Neapolitan friend stepped in to secure his release. Neither Mercer, nor Vansittart, nor Dempster could be absolved of responsibility for their respective experiences. Nonetheless, all three incidents stimulated British criticism of the administration of law and order in Italy. The Times condemned the 'brutal excesses' of the Italian authorities ${ }^{28}$, and suggested that the Italian police were perhaps 'too military' in character and 'not sufficiently drilled into respect for the public'29.

These events had not been forgotten when a succession of further incidents led British spectators to question Italy's liberal credentials. In 1875 Theodore Tourrier and John O'Neill, an English resident of Florence and a New Zealander touring Italy, were arrested near Forlì in Romagna ${ }^{30}$. When a carabiniere asked to see their passports they declared that British subjects were not required to carry them. When

22 TNA, FO 425/107, Opinion of the Advocate Giuseppe Romano upon the subject of the Indemnity due to Mr. William Mercer, 13 October 1874, and The Law Officers of the Crown and Dr Deane to the Earl of Derby, 18 December 1874.

23 Paget to Granville, 1 April 1873 and Vansittart to Paget, 31 March 1873, Correspondence Respecting an Attack on Mr Vansittart at Rome, BPP (1873, LXXV, pp. 661, 663-664).

24 Paget to Granville, 15 April 1873 (ibid., pp. 664-665).

25 Paget to Granville, 4 May 1873 (ibid., pp. 670-671); Plowden to Paget, 15 April 1873 (ibid., pp. 666667).

26 Visconti Venosta to Paget, copy and translation, 4 May 1873 (ibid., 675).

27 Extract from Libertà enclosed in Paget to Granville, 25 May 1873 (ibid., 675-657).

28 The Times, 18 April 1873.

29 The Times, 10 December 1872.

30 TNA, FO 425/107, Statement of Messrs Tourrier and O’Neill, 29 March 1875. 
the officer asked to see some other form of identification Tourrier produced a personal card and a stamped receipt, both of which were declared unsatisfactory. The two men were then searched, deprived of their possessions, and detained for the night without food. The following day they were manacled and marched to Ravenna, where they were interrogated by a magistrate who eventually ordered their release. Tourrier and O'Neill appealed to the British Legation for redress, whereupon Paget brought their case before the Italian government. Emilio Visconti Venosta, the Italian foreign minister, expressed regret and conceded that the officers had been overzealous in their enforcement of the law. However, he justified the action on account of the poor condition of public security in that region. He explained that although British subjects were not obliged to carry passports, the law did require them to be in possession of some form of identity document. Visconti Venosta refused to offer compensation to the travellers, but undertook to ensure that there would be no repeat occurrence ${ }^{31}$.

Within a month a Revd Kay was arrested after his coach had stopped at Avenza near Carrara in Tuscany. The Briton's unusual mode of dress - which appears to have included a pith helmet - attracted the attention of three carabinieri, whose sergeant asked to see his passport. Kay refused to comply and stated with indignation that he had travelled extensively in Italy without ever being asked for one. The sergeant informed him that to be without a passport was an offence liable to imprisonment, whereupon all three officers allegedly wrestled the traveller to the ground before dragging him off to their barracks. According to his version of events, Kay was then subjected to a violent drunken condemnation of the English, who believed that 'they could go wherever they pleased and behave however they liked'. Despite offering other documents as proof of his identity and asking to telegraph the British consul at Livorno to whom he was known, he was detained in a small and dirty cell. He had to purchase food and drink at his own expense, and he requested but did not receive medical attention. He accused the sergeant of taunting him by pretending to acquiesce in his request for a better room before returning him to the original one. In the middle of the night the sergeant showed some concern that his prisoner was in fact Prussian or Russian, but after further questioning the following day the Briton was released. Kay admitted ignorance as to the exact regulations regarding passports. He acknowledged that if they were obligatory then he was indeed at fault. But he declared that if they were not, he was the victim of a 'wanton outrage ${ }^{32}$. The case prompted Paget angrily to observe: 'Either British subjects have the right of travelling in Italy without a passport, or they have not ${ }^{33}$.

The situation was soon compounded by the experience of two brothers, Henry and Edward Allies, who were touring near the Swiss frontier. While resting at the side of the road, they were approached by a solitary carabiniere who asked to see their passports. The brothers responded that British subjects were not obliged to carry them. According to their version of events, this made the officer 'still more impertinent', whereupon Henry made the critical error of calling him an 'insolent fellow'. At this remark the sergeant purportedly flew into a rage, flattening his accuser on the ground, handcuffing him, and subjecting him to an undignified

\footnotetext{
31 TNA, FO 425/107, Paget to Derby, 26 April 1875, and Visconti Venosta to Paget, 22 April 1875.

32 TNA, FO 425/107, Statement of the Revd D. Kay, 25 May 1875.

33 TNA, FO 425/107, Paget to Derby, 30 May 1875.
} 
search which revealed him to be a Catholic priest. The officer marched his prisoner six miles to Etroubles, allegedly insulting him all the way. After a night in a cell, Henry was handcuffed again and marched to Aosta. There, he was charged with 'resisting arrest with violence and using foul language against an agent of the public force' before being released on bail for 250 francs. At his trial Henry was found guilty and fined 100 lire. Strangely, despite also failing to show a passport, Edward had been free to go, but he had refused to abandon Henry and was imprisoned without charge. The Allies brothers appealed to the British Legation for 1000 francs each in compensation ${ }^{34}$.

In response to Paget's representations, Visconti Venosta ordered that an enquiry be carried out during the summer of 1875 . Since 1862 British nationals had not been required to carry passports in Italy, but the 1865 Law on Public Safety decreed that all persons - whether Italian or otherwise - should carry proof of identity at all times. Tourrier and O'Neill had been in violation of this law, but Visconti Venosta described their treatment as a 'regrettable mistake' for which the officers concerned had been disciplined. Kay had also broken the law, not by failing to carry a passport, but for having one and refusing to present it for inspection. He had also registered under a false name at his hotel ${ }^{35}$; this constituted a further offence, and raised questions regarding the nature of his business. Visconti Venosta pointed out that Tourrier, O'Neill and Kay were all entitled to sue their assailants as private individuals rather than as representatives of the State ${ }^{36}$. The same possibility lay open to Edward Allies, whose treatment had been undoubtedly unlawful. However, the case of Henry Allies was complicated by the fact that he had been found guilty and fined, before declining his right to appeal; the government could not violate the independence of the courts by annulling the verdict and reimbursing $\mathrm{him}^{37}$. In an effort to prevent further incidents the Italian government issued a circular clarifying the responsibilities in such matters of the Carabinieri, the State Police, and the National Guard. This cited the arrests of Tourrier and O'Neill, Kay, and the Allies brothers as examples of an overly rigorous interpretation of the law. It stipulated that foreigners should be approached only if they aroused suspicion, and that they should be restrained only if attempting to escape. The document also clarified that passports were not compulsory, but that all persons should nevertheless carry some form of identification ${ }^{38}$. This information was published in the British press, along with the additional recommendation that individuals should be always cooperative, and never obstructive or abusive ${ }^{39}$. The foreign minister insisted that failure to carry a passport would never be the sole cause for the arrest of a British subject in Italy. However, he expressed his hopes that Britons might make greater effort to comply with Italian law and that they might behave with 'better will' in future.

In Britain the Conservative government remained dissatisfied. Lord Derby, the foreign secretary, announced that Britain's goodwill towards Italy derived largely

\footnotetext{
34 TNA, FO 425/107, H.B. Allies to Paget and E.H. Allies to Paget, 10 June 1875.

35 TNA, FO 425/107, Précis of Evidence taken at the Special Enquiry held at Avenza, before the President of the Tribunal of Massa, respecting the Arrest of the Revd D. Kay.

36 TNA, FO 425/107, Visconti Venosta to Paget, 20 June 1875.

37 TNA, FO 425/107, Visconti Venosta to Paget, 20 August 1875.

38 TNA, FO 425/107, Paget to Derby, 7 August 1875.

39 The Times, 12 August 1875.
} 
from the hospitality that British visitors received from the Italians. He hoped that the growing impression that they could be treated 'with ignominy and brutality' by the Italian police without prospect of indemnity might be banished ${ }^{40}$. Nonetheless, the Italian government maintained its position into $1876^{41}$, when - as if to vindicate it Richard Greenhaigh managed to get himself arrested while waiting for a train at Capua in Campania. When two carabinieri approached asking to see his passport, the traveller refused to present it on two counts: first, he did not think that they had any right to demand it; secondly, he thought that he had left it in his hotel. His obstructive behaviour aroused their suspicions further, so they arrested him and detained him at the barracks. As soon as their superior arrived Greenhaigh was released, though - to his annoyance - not soon enough for him to catch his train. The enraged Briton telegraphed the interior ministry demanding a written apology, the punishment of the officers, and expenses for the cost of his telegram. Later, he claimed that he could forgo the apology, but insisted upon compensation ${ }^{42}$. Once again Visconti Venosta expressed regret and ensured that punishments were meted out, but he refused to take any further steps on account of Greenhaigh's uncooperative attitude ${ }^{43}$. Soon afterwards the Italian elections brought about a change of government, whereby the ruling administration of the Liberal Right was replaced by an ostensibly more progressive one of the Liberal Left. Paget sought to take advantage of this change by warning that the succession of incidents was damaging British confidence in Italian justice ${ }^{44}$. The new ministry published a circular instructing its officials to act in a strictly legal manner, but it did not depart from the position of its predecessor regarding the payment of compensation to British complainants. Consequently, the Foreign Office was forced to concede that nothing more could be done through diplomatic channels ${ }^{45}$.

With reluctance, the British government had come to accept this state of affairs when two further incidents occurred, each more shocking than previous cases. In September 1876 Paul Rainford, a resident of Taormina in Sicily, was enjoying a local festa with his friend Claud Monckton, when they were approached by a group of carabinieri. Despite not being in uniform a deputy sergeant named Resconi demanded proof of their identity. When Rainford and Monckton offered to go home to fetch their passports, the suggestion was rejected. There followed a verbal altercation regarding an Englishman's obligation to carry identification and the rights of an officer to ask for it. Rainford described Resconi's tone as 'insolent' and 'offensive', observing that it was strange he should be asked to prove his identity in a town where he had lived for seven years. Rainford and Monckton were arrested and marched off in humiliating fashion in front of a large crowd. They were imprisoned in a dark room infested with vermin and rendered 'pestiferous from accumulated filth of all kinds'; it was only through the help of friends that they were provided with a candle, food, and mattresses. That evening they were visited both by the

\footnotetext{
40 TNA, FO 425/107, Derby to Paget, 13 September 1875.

41 TNA, FO 425/107, Visconti Venosta to Paget, 8 Feburary 1876.

42 TNA, FO 425/107, Paget to Derby, 13 March 1876.

43 TNA, FO 425/107, Visconti Venosta to Paget, 21 March 1876.

44 TNA, FO 425/107, Paget to Derby, 10 April 1876.

45 TNA, FO 425/107, Lister to Tourrier, adapted version of which was also sent to the Allies brothers, 13 October 1876, and Malet to Kay, 21 October 1876.
} 
mayor and the magistrate, each of whom claimed to be unable to do anything for them. Resconi was alleged to have taunted his prisoners with the ominous exclamation: 'You are in Italy, and, by God! we have a Government which does not allow you to breathe ${ }^{46}$. Only in the morning were they released.

Both men demanded 'heavy pecuniary compensation' from the Italian government for arbitrary imprisonment, insults, humiliation, and for detriment to Rainford's health. George Dennis, the British consul at Palermo and a personal acquaintance of Rainford, reacted with disgust and no apparent thought of self-restraint. The consul informed the foreign secretary of the 'tyrannical and brutal conduct' of the 'vulgar and ignorant subaltern' Resconi, and the 'contemptuous indifference' of the magistrate $^{47}$. In Paget's absence his secretary requested that Resconi be punished and that the conduct of the mayor and magistrate be investigated ${ }^{48}$. There were reports that Rainford's language had not been of the variety best calculated to improve the situation, but a number of local people enjoyed good relations with him and paid tribute to his good character ${ }^{49}$. Furthermore, it seems that Rainford was already acquainted with Resconi. On one occasion he had reported a robbery at his home, while on another he had encountered Resconi and his colleagues in his garden and expelled them. Rainford thought that the episode was retribution for this previous encounter, while Dennis pointed out that Resconi was unlikely to have failed to recognize the Englishman on account of his having only one eye. The apparent collusion of the mayor and the magistrate was eventually attributed to the fact that Rainford's property was a former convent, the sale of which to a Protestant foreigner was resented by local officials who were 'under the influence of the priests ${ }^{50}$.

In a farcical turn of events Rainford and Monckton sued Resconi for arbitrary arrest and imprisonment, only to have the judge turn the case against them ${ }^{51}$. The Englishmen appealed to the British ambassador, protesting that if they were tried the verdict could only go one way because the court officials were all friends of the mayor ${ }^{52}$. Rainford accused them of perverting and suppressing evidence ${ }^{53}$, and attempted to have another judge assigned to the case ${ }^{54}$. Paget sought unsuccessfully to have the hearing postponed until the matter could be investigated fully ${ }^{55}$. The charges against Monckton were dropped on account of his inability to speak Italian, but Rainford was tried, found guilty and fined 100 francs plus costs for causing

46 TNA, FO 425/107, Monckton to Rickards, 18 September 1876 and Rainford to Rickards, 19 September 1876.

47 TNA, FO 425/107, Dennis to Derby, 22 September 1876.

48 TNA, FO 425/107, Malet to Melegari (wrongly cited as Malet to Visconti Venosta), 25 September 1876.

49 TNA, FO 425/107, Testimonial addressed to Mr Rainford by the 'Società Operaja' of Taormina, 1 October 1876, 28 signatures, and Testimonial addressed to Mr Rainford by the Inhabitants of Taormina, 22 September 1876, 110 signatures.

50 TNA, FO 425/107, Malet to Derby, 25 September 1876.

51 TNA, FO 425/107, Rainford and Monckton to Dennis, by telegraph, 4 March 1877.

52 TNA, FO 425/107, Rainford and Monckton to Paget, 6 March 1877.

53 TNA, FO 425/107, Rainford to Paget, 9 April 1877.

54 TNA, FO 425/107, Memorandum by Melegari, enclosed in Paget to Derby, 8 May 1877.

55 TNA, FO 425/107, Paget to Melegari, 31 March 1877 and Melegari to Paget, 9 April 1877. 
'outrage to public functionaries in the execution of their duties" ${ }^{56}$. Dennis reported serious inconsistencies between the verdict and the evidence: Rainford had been absolved of refusing to identify himself and his arrest was attributed to his offensive language; however, the evidence suggested that he had become abusive because he had been arrested. Moreover, he was accused of having called Resconi a coglione (bollock), but only one of the nineteen witnesses testified to having heard him use the term. Consequently Dennis declared that the trial lacked 'that regard to justice and fair-play which Englishmen expect' ${ }^{57}$. Fearing a repeat of the Allies scenario, whereby the payment of a fine was considered tantamount to an admission of guilt, the Foreign Office funded two appeals ${ }^{58}$. At the first the Court of Messina upheld the verdict $^{59}$, but at the second Rainford was acquitted by the Supreme Court of Palermo. By then, the administration of justice in Sicily had been severely criticized by The Times and considerable damage had been done to Italy's reputation in British eyes $^{60}$.

The Rainford case was still pending when one further incident finally exhausted Paget's patience and brought matters to a climax. In July 1877 a Revd Giles was staying at an inn at Isola del Liri near Frosinone. He was awoken at midnight when two carabinieri burst into his room demanding to know who he was. Giles presented a valid passport for inspection, only for the sergeant - whom he suspected to have been drinking - to declare erroneously that it was out of date. When the clergyman attempted to offer some other proof of his identity the officer came to the unfortunate conclusion that he was attempting to pass as someone else. Giles was taken to the barracks, deprived of his possessions, and locked in a small and dirty room for the night. The following day he was permitted access to the telegraph, and provided with food and coffee. Then he was transferred to nearby Sora, where he was questioned by two 'exceedingly polite' officials who compared his signature with that in his passport and ordered his release. When he thanked them for letting him go, Giles was told that the carabinieri concerned had merely done their duty.

Giles was probably the most innocent victim of the succession of 'outrages' perpetrated against British nationals in Liberal Italy. He was left to echo the opinion voiced by Cruickshank a decade before:

So it seems that this is a specimen of the annoyances and affronts [to] which an English gentleman, in this nineteenth century, travelling in the most open way along the high roads of their Kingdom of Italy, and with his papers in perfect order, is exposed... ${ }^{61}$

He revealed that a prefect had also cast doubt on the validity of his passport while he was touring the Gran Sasso d'Italia, and suggested that more explicit guidelines be issued to Italian officials and foreign travellers in order to prevent repeat occurrences ${ }^{62}$.

\footnotetext{
56 TNA, FO 425/107, Charges against Messrs Rainford and Monckton, translation.

57 TNA, FO 425/107, Dennis to Derby, 2 July 1877.

58 TNA, FO 425/107, Paget to Derby, by telegraph, 15 August 1877, and Derby to Paget, 15 August 1877.

59 TNA, FO 425/107, Dennis to Derby, 25 August 1877.

60 The Times, 30 October and 2 November 1877.

61 TNA, FO 425/107, Giles to Rector of the English College, 6 July 1877.

62 TNA, FO 425/107, Giles to Paget, 31 July 1877.
} 
The incident persuaded Paget that it was 'quite time' to have the Italian government put an end to the 'persecution and ill-treatment' of British subjects by the Carabinieri $^{63}$. He demanded that the Italian foreign minister explain why Giles had been disturbed, why his passport had not been accepted, and on what grounds the arrest could have been justified. In a breathless release of choler, he warned that:

\begin{abstract}
...unless something is done to prevent a repetition of these now constantly-recurring cases, the result will inevitably be to produce an estrangement in the place of the friendly feelings which have always so happily existed between the two Governments and the two nations, for it is perfectly intolerable that unoffending and respectable persons should, without having given the slightest provocation, or committed the smallest crime, be dragged out of bed in the dead of night, be conducted to prison, and then be paraded the next day through the public thoroughfares, escorted by the police, as though they were common malefactors or convicted felons ${ }^{64}$.
\end{abstract}

Finally, Paget enquired what measures would be taken in order to preserve British subjects in Italy 'from arbitrary and tyrannical proceedings on the part of those who ought to be their protectors'. In response to this final case, the British government issued a circular advising its nationals to carry passports at all times when in Italy.

The new Italian foreign minister, Luigi Melegari, reacted to the Giles case in the same way that Visconti Venosta had reacted to the previous incidents. He expressed regret, ordered a report, ensured the punishment of the officers concerned, and explained the need for vigilance in that locality. By now, though, the Italians had also had enough. In a decidedly irritable tone Melegari emphasized that while some Britons had been 'subjected to some annoyance' by the Carabinieri, the majority had been able to travel safely owing to their efforts. He observed that Italian governments had always responded with great deference to British protests ${ }^{65}$, and ordered the Italian ambassador in London to remonstrate with the Foreign Office over Paget's language ${ }^{66}$. Angrily, he drew attention also to a couple of incidents in which the English legal system had failed Italian nationals. The first case concerned a Signor Cerruti, who had been arrested and arbitrarily imprisoned by the Metropolitan police before being released and informed that he could seek compensation only through the courts ${ }^{67}$. Unlike the similar cases in Italy, this event had occurred not in some unruly backwater but in the heart of London. The second case involved a Signor Pellizzone, who had been wrongly convicted of murder and sentenced to death by a British court before being saved only by the confession of the culprit ${ }^{68}$. This miscarriage of justice had been far more outrageous than any police 'outrage' against Britons in Italy. On both occasions, however, Italian leaders and diplomats had respected English law and accepted that Italians in England were subject to it ${ }^{69}$.

63 TNA, FO 425/107, Paget to Derby, 10 July 1877.

TNA, FO 425/107, Paget to Melegari, 10 July 1877, enclosed in Paget to Derby, 10 July 1877.

TNA, FO 425/107, Melegari to Paget, 23 July 1877, in Paget to Derby, 27 July 1877.

66 Menabrea to Melegari, 1 August 1877, I documenti diplomatici italiani seconda serie: $1870-1896$ (DDI), Vol. IX (Rome, 1985, pp. 2-3).

67 For the Cerruti case, see TNA, FO 425/107, Melegari to Malet, 18 October 1876.

68 Serafino Pellizzone was tried and convicted for the murder of Michael Harrington on Saffron Hill in London, before it emerged that the guilty party was his cousin, Gregorio Mogni. See The Times, 28 December 1864, 4 and 9 February 1865.

69 Melegari to Menabrea, 4 September 1877, DDI, Vol. IX (pp. 65-68). 
They claimed to have demonstrated a far greater reserve than their British counterparts, whom they accused of protesting at the slightest offence against one of their subjects overseas. Even so, the foreign secretary refused to censure Paget for his tone, asserting that the ambassador had acted with the sanction of the British government $^{70}$. Paget made no apology, and even admitted to having used stronger language on other occasions ${ }^{71}$.

This rare moment of discord between the British and Italian governments was largely the result of a Victorian failure to understand the nature and scale of the challenges facing Liberal Italy. The country's unification had brought about the downfall of the ancien régime and replaced it with the modern bureaucratic State. In the former, power had rested with the privileged and propertied classes, including the Church; in the latter, it rested in theory with governments, but was delegated in practice to magistrates, civil officials, and the police ${ }^{72}$. In essence, this change occurred during the political unification of the peninsula between 1859 and 1870, but it took decades for the new order to assert itself over the old. Consequently, the 1860s and 1870 s should be seen as a transitional period during which Liberal Italy struggled to establish itself. The vacuum created by the collapse of Italy's autocratic predecessor states permitted a surge in crime, corruption, and violence as a formidable array of opponents lined up against the new kingdom. The Italian government faced hostility from supporters of the deposed monarchies, clerical reactionaries and republicans at first, socialists and anarchists later on, and impoverished peasants throughout. The inhabitants of many of the territories annexed to Piedmont felt that they had been conquered by the Piedmontese rather than united with them as equals $\mathrm{s}^{73}$. The army had to be mobilized to crush major revolts in southern Italy (1861-65), Sicily (1866), Sardinia (1868), and central Italy (1868-1869) ${ }^{74}$. In a sense, the Britons who clashed with Italy's law enforcers had walked right into this crisis.

From 1861 Italy was ruled by the Liberal Right, whose achievements included administrative and legal fusion, monetary union, the standardization of weights and measures, and the construction of a rail network ${ }^{75}$. From 1876 it was ruled by the more progressive Liberal Left, who abolished capital punishment and extended state education and the electoral franchise ${ }^{76}$. Both factions were genuinely committed to the liberalization of their country ${ }^{77}$, but their efforts were compromised by a dire economic crisis, a crippling lack of legitimacy, and a constant preoccupation with national security. Although they admired British institutions, Italian leaders did not believe their country to be 'ready' for civilian policing on the Victorian model ${ }^{78}$.

\footnotetext{
70 Menabrea to Melegari, 28 August, 1877, DDI, Vol. IX (pp. 56-57).

71 TNA, FO 425/107, Paget to Tenterden, 27 July 1877.

72 See Emsley (2007, p. 9).

73 Doumanis (2001, pp. 86-91).

74 For the brigands' war in southern Italy see Molfese (1966); for the Palermo revolt in Sicily see Riall (1998, pp. 198-221); for the Nuoro revolt in Sardinia see Todde (1971, pp. 217-230); for the Macinato riots in central Italy see Davis (1988 pp. 190-192).

75 For the fusion see Aquarone (1960). For the challenges of monetary union see Candeloro (1968, pp. 235-239). For the construction of the rail network see Schram (1997).

76 Duggan (2007, pp. 315-316).

77 Cilibrizzi (1939-1952, pp. 92-93).

78 Hughes (1996, pp. 22-31), cited in Emsley (1999).
} 
Prior to the Napoleonic invasion the closest that many parts of Italy had come to having a regular police force were the contemptible sbirri, irregular bodies of heavily-armed but often ignorant and corrupt men with an appalling reputation for arbitrary behaviour ${ }^{79}$. In an effort to improve the efficiency and standing of their law enforcers several of Italy's predecessor regimes had established regular armies of gendarmes to share the duties of policing with small civilian forces. The Italian Carabinieri originated in Piedmont and were inherited by Liberal Italy. They had developed a prestigious reputation as defenders of the Savoyard monarchy and as combatants in the wars of the Risorgimento ${ }^{80}$. Like the Gendarmeria of Napoleonic Italy in whose image they had been created ${ }^{81}$, the Carabinieri were charged simultaneously with the establishment of a new political order and the preservation of the social status quo. The fact that the Guardia di Pubblica Sicurezza, Liberal Italy's fledgling civilian police force, was small and confined within urban districts ensured that the Carabinieri assumed the greatest responsibility for policing; this was especially the case in the vast and hazardous rural areas where the authority of the State was under greatest threat. As the representatives of the Liberal State with whom the populace were most likely to come into contact, the Carabinieri were intended to be representatives of good government and equality before the law. Recruits were required to be of sound moral character, received a military training, and were subject to military discipline. However, they were often very young, poorly educated and poorly paid men performing a difficult and very dangerous $\operatorname{task}^{82}$. As a result of the considerable powers at their disposal, their role in suppressing insurrections, and their status as the agents of a government which lacked legitimacy in the eyes of many of its citizens, they acquired an unfortunate reputation as instruments of repression ${ }^{83}$.

Liberal Italy maintained a higher standard of policing than its predecessor states, some of which had resorted to torturing prisoners, corporal punishment, and summary execution. Nonetheless, there was continuity with the past. In Austrian-ruled Venetia the police had kept potential troublemakers under close surveillance, and had treated foreign travellers with suspicion ${ }^{84}$. In the Papal States police surveillance had been intrusive and the practice of making preventive arrests had been widely employed ${ }^{85}$. In Bourbon Sicily gendarmes were prone to disregarding regulations on dress, waging personal vendettas, and acting arbitrarily when conducting searches and making arrests; they were also susceptible to the influence of local elites $^{86}$. To some extent, all of these practices reverberated in Liberal Italy. Although the new kingdom was governed under the Piedmontese statuto of 1848, one of the most liberal constitutions in Europe, the 1865 Law on Public Safety was a stern reaction to the alarming state of upheaval in the country, and represented something of a return to absolutist methods in policing. Italian leaders did not resort to a pro-

\footnotetext{
79 Hughes (1994, pp. 11-14).

80 For a history of the Carabinieri, see Calanca (1983-1988).

81 Broers (1996).

82 Davis (1988, pp. 232-234).

83 See Emsley (1999, pp. 191-206).

84 Laven (1996).

85 Hughes (1994, pp. 223-225).

86 Fiume (1991; in particular, see pp. 84-86).
} 
gramme of constant repression, but the police were awarded extensive and generally increasing powers ${ }^{87}$. They were equipped with wide-ranging methods of surveillance and could make arrests or issue cautions upon mere suspicion ${ }^{88}$; even a verbal insult against an officer could result in imprisonment ${ }^{89}$. On occasion, Liberal Italian governments showed themselves prepared to impede the press, prohibit public meetings, imprison criminal suspects and revolutionaries without trial, and to impose internal exile upon individuals who could not be prosecuted ${ }^{90}$. Only the Cairoli government of 1878 proposed a policy of 'liberty within the law', and collapsed when it sought to implement it ${ }^{91}$.

Most of the incidents covered here occurred in remote and often mountainous zones where communications were poor, brigandage and vendetta endemic, and where local populations would employ their own dialects and other means to undermine government authority ${ }^{92}$. The Carabinieri were just as entitled to be on their guard in rural Romagna where Tourrier and O'Neill were apprehended, and the countryside outside Rome where Giles was accosted, as in the notoriously wild southern mainland and the islands of Sardinia and Sicily. They had every reason to be suspicious of foreigners who were unable to provide evidence of their identity, and even greater cause for suspicion of those who refused to do so. Garibaldi had depended very much upon the support of foreign volunteers, and both the reactionary and republican opponents of Liberal Italy included foreign activists. London was renowned on the Continent as a safe haven for European exiles ${ }^{93}$, and it was in England that the Italian nationalist Felice Orsini had planned his 1858 attempt to assassinate Napoleon III ${ }^{94}$. In 1861 a Bourbon activist captured in a Naples hotel raid produced a British passport and claimed falsely to be British ${ }^{95}$. In 1862 a young Englishman was captured carrying documents detailing another conspiracy across the Italo-Roman frontier ${ }^{96}$. In 1865 a couple of Maltese-born British subjects were arrested in Messina on suspicion of involvement in a further anti-government plot ${ }^{97}$. Mazzini spent much of his life in exile in London, and is thought to have stayed with a British family near Lake Como during the late $1860 \mathrm{~s}^{98}$; one member of that family then led a revolutionary band in northern Italy at the end of the decade ${ }^{99}$. Under these

\footnotetext{
87 See Jensen (1991).

88 Davis (1988, pp. 227-228).

89 Rizzo (2005).

90 Clark (1996, pp. 51-55); Mack Smith (1997, pp. 106-107); Davis (1988, pp. 213-214; 223-226).

91 Seton-Watson (1969, pp. 76-77).

92 For examples, see Scott (1987); Riall (1992).

93 Thurmond Smith (1985, pp. 79-112).

94 St John Packe (1957, pp. 265-266).

95 For the case of Count Cristen, see TNA, FO 45/9, Bonham to Hudson, 7 September 1861 and Hudson to Russell, 19 September 1861.

96 For the case of James Bishop, see Papers relating to Treatment of Political Prisoners in Confinement at Naples, and Arrest of Mr Bishop, BPP, 1862 LXIII 493.

97 For the case against Felice Attardi and Rosario Messina, see TNA, FO 45/74, Herries to Clarendon, 29 October 1865; TNA, FO 45/85, Elliot to Clarendon, 16 March 1866.

98 On the Nathan family see Mack Smith (1994, pp. 118-119; 213-215).

99 On Joseph Nathan, see TNA, FO 45/140, Paget to Clarendon, 21 April 1869; TNA, FO 45/144, Paget to Clarendon, 14 November 1869; TNA, FO 45/163, Paget to Clarendon, 2 and 9 June 1870.
} 
circumstances British nationals could not expect to be exempt from suspicion. Furthermore, it is hardly surprising that several were approached while at important points of passage such as railway stations and highways, or in close proximity to international frontiers.

Besides their British nationality, one factor which links most of these cases is religious identity, whether Protestant or Catholic, actual or apparent. The Roman Catholic Church was the most subversive organization in early Liberal Italy, accusing the Italian government of overthrowing the temporal sovereignty of the pope by force when Rome was occupied in 1870. The Church was hostile to the State's 'lay morality' of liberalism, rationality and progress, which challenged its traditional influence over society ${ }^{100}$. The Italian government expropriated and sold its lands and disbanded certain religious orders. These measures were extended to Rome in 1873, the same year that the Catholic Vansittart was attacked by the anticlerical mob. Cruickshank was a Catholic priest whose behaviour suggests that he had something to hide at a time when Garibaldi was preparing to march on Rome. Henry Allies was a Catholic priest, and the carabiniere who arrested him showed little interest in his brother Edward, who had no obvious connection with the Church. The Revds Kay and Giles both appear to have been Protestant clergymen; they might have been approached on the mistaken assumption that they were Catholics, but they could just as easily have been targeted because they were Protestants. Rainford, as a Protestant Englishman who had bought a convent through the State's secularization of Church lands, seems to have been the victim of a local vendetta. It is even feasible that Tourrier, O'Neill, and Greenhaigh - none of whom were churchmen - were questioned because, as British nationals, they were presumed to be Protestants. It is more likely, however, that these individuals attracted attention simply because they were strangers in remote parts of Italy which were unaccustomed to foreign visitors. Further research might aim to consider how British experiences compared with those of individuals from other states strongly identified as Protestant or Catholic powers, or which were remembered for having played a particularly pro- or anti-Italian role during the Risorgimento.

If the British government and its representatives did not appreciate the scale of the problems posed to Liberal Italy by its enemies, they also failed to acknowledge the culpability of their compatriots who travelled the country in ignorance of its laws. In most cases it is probable that the attentions of the Carabinieri would have been allayed by politeness and the presentation of a valid identity document. British travellers appear frequently to have been confused by Italian regulations stipulating that, although visitors were not obliged to bear a passport, all persons should be in possession of some form of identity document. Moreover, unlike their continental neighbours, nineteenth-century Britons were not habituated to carrying proof of their identity unless crossing a frontier ${ }^{101}$. Nonetheless, those who failed to comply with Italian law all bore considerable responsibility for their experiences. The Baedeker guides for northern and central Italy alerted travellers to the fact that they might be asked to present their credentials in remote districts ${ }^{102}$. Even before the succession of 'outrages' the corresponding guide for southern Italy referred to the

\footnotetext{
100 Clark (1996, pp. 81-85).

101 Fahrmeir (2001, p. 233).

102 Baedeker (1877a, p. xiv; 1877b, p. xiv).
} 
passport as 'an essential companion', and warned that the failure to carry one might result in detention ${ }^{103}$. It should be acknowledged, however, that even complete compliance with the law did not necessarily provide a guarantee against molestation; Giles was detained without having committed any offence whatsoever, and despite being genial and cooperative through his ordeal. His experience could have been a result of the strain placed upon the men policing such unruly districts as rural Lazio. Alternatively, it could have been the result of an anti-British sentiment which officers might have felt as a result of previous encounters with British visitors. This certainly appears to have been a factor in Kay's case; his arrest occurred in Tuscany, one of the most popular destinations for British travellers, and the carabiniere concerned was alleged to have expressed his hatred of the English. In Italy British tourists had acquired a reputation for arrogance and loutishness during the days of the Grand Tour ${ }^{104}$; the behaviour of Kay and his kind did not ameliorate it.

The Italian government was mystified as to why its British counterpart should be so quick to protect individuals who travelled without due regard for the laws and customs of their hosts. Throughout the nineteenth century British governments generally employed their naval mastery towards the maintenance of peace ${ }^{105}$, but they had been known to abuse their power. The most notorious example of British gunboat diplomacy was the Don Pacifico affair of 1850, when the Royal Navy blockaded Athens in response to an attack on the home of a Gibraltar-born Portuguese Jew who claimed British subject status ${ }^{106}$. There had almost been a repeat occurrence during the Cagliari affair of 1858, when the Italian revolutionary Carlo Pisacane had hijacked a steamer and launched a disastrous invasion of the Kingdom of the Two Sicilies. Two British engineers employed onboard the steamer were arrested by the Neapolitan government, and imprisoned for many months before the case against them was dropped. When the British suggestion that the Neapolitan authorities should compensate the men was rebuffed, a Conservative government threatened naval action in order to ensure compliance ${ }^{107}$. Even after the Unification of Italy British gunboats were active in Italian waters. In 1865 one was involved in an attempt to facilitate the release of two British travellers who had been kidnapped by brigands in Campania ${ }^{108}$. In 1870 another was deployed to protect a British viceconsul who had become the target of a local vendetta ${ }^{109}$. In neither case was there any attempt to bully the Italian government, but such assertive behaviour incited the Italian premier Giovanni Lanza to protest that Italy 'was not to be treated as the Barbary State ${ }^{\prime 110}$.

This accusation is noteworthy for the implication that, far from being treated as an equal by Britain, Italy was not always treated even as a friendly European power.

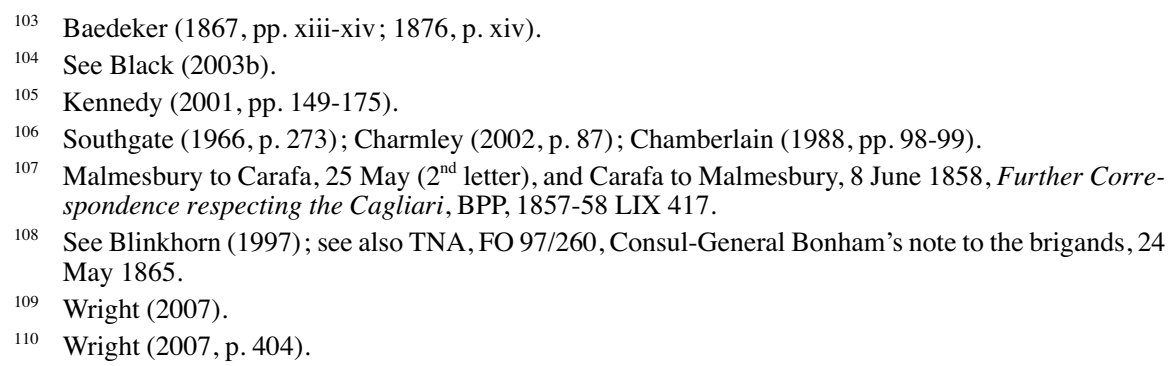


This article has revealed cultural contrasts between the respective outlooks of the British and Italian States towards policing and the freedom of the individual. But it is also possible to interpret the behaviour of British residents, travellers and diplomats in Italy as manifestations of their prejudice against southern Europeans. Occasionally Britain's handling of Liberal Italy evoked something of its behaviour towards the Greeks in 1850 and the Neapolitans in 1858. A decade after the Unification of Italy the foreign secretary Lord Clarendon dismissed the Italians as being no more suited for representative government than the Spanish ${ }^{111}$. British diplomats had a long history of lecturing Italian rulers ${ }^{12}$. Among them, Paget is remembered as a man who might have lacked 'the qualities which make a great diplomatist' but who won the confidence of foreign governments through his 'upright, straightforward, and manly character" ${ }^{113}$. His wife described him as "fearless in expressing his views ${ }^{114}$, and it is significant that his outspokenness had caused friction during his earlier career in Denmark ${ }^{115}$. By 1877 the patronizing attitude of Paget and his predecessors had become offensive to an Italy which considered itself one of the Great Powers. It is ironic that the British Legation in Rome had been upgraded to Embassy status in 1876 as a courteous acknowledgement of this ranking ${ }^{116}$. The Italian ambassador in London, Luigi Menabrea, believed that the Conservative government ought to be reminded of Sir Robert Peel's criticism of Palmerston's action over the Don Pacifico affair, the former leader having argued that diplomacy was intended to preserve the peace and not to provoke resentment, hostility, and $\operatorname{war}^{117}$. Menabrea suggested aptly that too many Britons believed that their status as 'sons of Albion' conferred automatic protection when overseas ${ }^{118}$. Even The Times acknowledged that Britons were sometimes too quick to cry 'Civis Anglicanus sum', and suggested that they 'endeavour to keep their tempers" ${ }^{119}$. While the Carabinieri would no doubt have concurred, Italian leaders might have wished to see the advice extended to include British foreign secretaries and diplomats.

Owain J. Wright
University of Worchester
Institute of Humanities and Creative Art
Henwick Grove
UK-Worchester WR2 6AJ
o.wright@ worc.ac.uk

111 Clarendon was never enthusiastic about the Unification of Italy, but his reference to how the Italians' reputation had declined was poignant nonetheless; see Clarendon to Paget, 13 December 1869, copy, Clarendon Papers, Bodleian Library, MS. Clar. dep. c. 475.

112 For examples see Ashley (1879, Vol. 2, p. 425); Marshall (1966, p. 199); Elliot, (1922, pp. 4-5); TNA, FO 167/122, Russell to Hudson, 21 January 1861; Clarendon to Elliot, 12 March 1866, in Il problema veneto e l'Europa, 1859-66, vol. II: Inghilterra, ed. Noel Blakiston, Venice (1966, pp. 784-785).

113 The Times, 13 July 1896; Dictionary of National Biography, Vol. 42 (pp. 338-339).

114 Paget (1924,pp. 208-209).

115 Waterfield (1963, p. 299).

116 Derby to Queen Victoria, 19 February 1876, in The Letters of Queen Victoria 1862-78, ed. George Earle Buckle, London (1926-1928, Vol. II, pp. 447-448).

117 Menabrea to Melegari, 17 November 1877, DDI, Vol. IX (pp. 202-203).

118 Menabrea to Melegari, 14 August 1877, DDI, Vol. IX (pp. 33-35).

119 The Times, 12 August 1875. 


\section{REFERENCES}

\section{Archival Primary Sources}

British Foreign Office, Political and Other Departments: Correspondence before 1906, 'Italy', The National Archives.

British Foreign Office and Predecessors, Political and Other Departments: Supplements to General Correspondence before 1906, 'The Case of Mr Moens', The National Archives.

British Foreign Office, Confidential Print Western Europe, 'Italy. Police Outrages on British Subjects in Italy and on Italian Subjects in Great Britain. Correspondence 1873-1878', The National Archives.

British Parliamentary Papers, Correspondence Respecting an Attack on Mr Vansittart at Rome, 1873, LXXV, 661.

British Parliamentary Papers, Further Correspondence respecting the Cagliari, 1857-1858, LIX, 417.

British Parliamentary Papers, Papers relating to Treatment of Political Prisoners in Confinement at Naples, and Arrest of Mr Bishop, 1862, LXIII, 493.

British Parliamentary Papers, Correspondence relating to Case of Count Guicciardini, 1854, LXXII, 809.

British Parliamentary Papers, Correspondence respecting the Case of Francesco and Rosa Madiai, 1851-1853, 1852-1853, CII, 633.

British Parliamentary Papers, Correspondence relating to the recent Case of the Imprisonment of Miss Cunninghame at Florence, 1854-1855, LV, 303.

Clarendon Papers, Bodleian Library, Oxford.

Dictionary of National Biography, Oxford, 2004.

I documenti diplomatici italiani seconda serie : 1870-1896, Vol. IX, Rome, 1985.

Il problema Veneto e l'Europa 1859-1866: raccolta di documenti diplomatici a commemorare il centenario dell'unione di Venezia e del Veneto allo Stato Italiano, Vol. II: Inghilterra, ed. Blakiston, N., Venice, 1966.

The Times Newspaper, 1864-1896.

\section{Printed Primary Sources}

Ashley, E., The Life and Correspondence of Henry John Temple, Viscount Palmerston, 2 vols, London, 1879.

Baedeker, K., Italy. Handbook for Travellers. Third Part: Southern Italy, Sicily, the Lipari Islands, Leipzig and London, 1867.

Baedeker, K., Italy. Handbook for Travellers. Third Part: Southern Italy and Sicily, with excursions to the Lipari Islands, Malta, Sardinia, Tunis, and Corfu, $6^{\text {th }}$ Edn, Leipzig and London, 1876.

Baedeker, K., Italy. Handbook for Travellers. First Part: Northern Italy, including Leghorn, Florence, Ravenna, the island of Corsica and routes through France, Switzerland and Austria, $4^{\text {th }}$ Edn, Leipzig and London, 1877a.

Baedeker, K., Italy. Handbook for Travellers. Second Part: Central Italy and Rome, $5^{\text {th }}$ Edn, Leipzig and London, $1877 \mathrm{~b}$.

Elliot, H.G., Some Revolutions and Other Diplomatic Experiences, London, 1922.

Gladstone, W.E., Two Letters to the Earl of Aberdeen on the State Prosecutions of the Neapolitan Government, London, 1851. 
Moens, W., Briganti italiani e viaggiatori inglesi : Lo straordinario resoconto di un sequestro nella Campania dell '800, Milan, 1997.

Paget, W., In My Tower, London, 1924.

Selections from Speeches of Earl Russell 1817 to 1841 and from Despatches 1859 to 1865, 2 vols, London, 1870.

The Letters of Queen Victoria 1862-78, ed. Buckle, G.E., London, 1926-1928, Vol. II.

\section{Secondary Sources}

Agar, J., Modern horrors: British identity and identity cards, in Caplan, J. Torpey, J. (eds), Documenting Individual Identity, Princeton and Oxford, 2001, pp. 101-120.

Aquarone, A., L'unificazione legislativa e i codici del 1865, Milan, 1960.

Beales, D., England and Italy 1859-1860, London, 1961.

Beales, D., Garibaldi in England: The Politics of Italian Enthusiasm, in Davis, J.A., Ginsborg, P. (eds), Society and Politics in the Age of the Risorgimento, Cambridge, 1991, pp. 184-216.

Black, J., Convergence or Divergence? Britain and the Continent, Basingstoke, 1994.

Black, J., Italy and the Grand Tour, New Haven and London, 2003a.

Black, J., The British Abroad: The Grand Tour in the Eighteenth Century, Stroud, 2003b.

Blinkhorn, M., Liability, Responsibility and Blame; William Moens, ed. Madeline Merlini, Briganti italiani e viaggiatori inglesi: Lo straordinario resoconto di un sequestro nella Campania dell '800, Milan, 1997.

Blinkhorn, M, Liability, Responsibility and Blame: British Ransom Victims in the Mediterranean Periphery, 1860-1881, Australian Journal of Politics and History, Autumn, 2000, 46, 3, pp. 336-356.

Bourne, K., The Foreign Policy of Victorian England 1830-1902, Oxford, 1970.

Bradford, E., Mediterranean : Portrait of a Sea, London, 2000; originally 1971.

Brand, C.P., Italy and the English Romantics: The Italianate Fashion in Early NineteenthCentury England, Cambridge, 1957.

Broers, M., The Police and the Padroni: Italian Notabili, French Gendarmes and the Origins of the Centralized State in Napoleonic Italy, European History Quarterly, Summer 1996, 26, 3, pp. 331-353.

Brooks, C., Antonio Panizzi: Scholar and Patriot, Manchester, 1931.

Calanca, A., Storia dell'arma dei Carabinieri, 3 vols, Foggia, 1983-1888.

Candeloro, G., Storia dell'Italia moderna, Vol. V: La costruzione dello Stato unitario, Milan, 1968.

Carter, N.E., Sir James Hudson, British Diplomacy and the Italian Question : February 1858 to June 1861, $\mathrm{PhD}$ thesis, University of Wales Cardiff, 1993.

Carter, N., Hudson, Malmesbury and Cavour: British Diplomacy and the Italian Question, February 1858 to June 1859, Historical Journal, Summer 1997, 40, 2, pp. 389-413.

Cavaliero, R., Italia Romantica : English Romantics and Italian Freedom, London, 2005.

Chamberlain, M.E., 'Pax Britannica?' British Foreign Policy 1789-1914, London \& New York, 1988.

Chaney, E., The Evolution of the Grand Tour: Anglo-Italian Cultural Relations since the Renaissance, London, 2000.

Charmley, J., Palmerston: 'Artful Old Dodger' or 'Babe of Grace'?, in Otte, T.G. (ed.), The Makers of British Foreign Policy: From Pitt to Thatcher, Basingstoke, 2002. 
Cilibrizzi, S., Storia parlamentare, politica e diplomatica d'Italia: Vol. II, Naples, 19391952.

Clark, M., Modern Italy 1871-1995, $2^{\text {nd }}$ Edn, Harlow, 1996.

Davis, J.A., Conflict and Control: Law and Order in Nineteenth-Century Italy, Basingstoke, 1988.

De Leonardis, M., L'Inghilterra e la Questione Romana 1859-1870, Milan, 1980.

Doumanis, N., Inventing the Nation: Italy, London, 2001.

Duggan, C., The Force of Destiny: A History of Italy since 1796, London, 2007.

Emsley, C., Gendarmes and the State in Nineteenth-Century Europe, Oxford, 1999.

Emsley, C., Crime, Police, and Penal Policy: European Experiences 1750-1940, Oxford, 2007.

Fahrmeir, A., Governments and Forgers: Passports in nineteenth-century Europe, in Caplan, J., Torpey, J. (eds), Documenting Individual Identity, Princeton \& Oxford, 2001, pp. 218 234.

Fiume, G., Bandits, violence, and the organization of power in Sicily in the early nineteenth century, in Davis, J.A., Ginsborg, P. (eds), Society and Politics in the Age of the Risorgimento, Cambridge, 1991, pp. 70-91.

Ginsborg, P., After the Revolution: bandits on the plains of the Po 1848-54, in Davis, J.A., Ginsborg, P. (eds), Society and Politics in the Age of the Risorgimento, Cambridge, 1991, pp. 128-151.

Gopal, S., Gladstone and the Italian Question, History : Journal of the Historical Association, 1956, 41, 141-143, pp. 114-121.

Hoppen, K.T., The Mid Victorian Generation 1846-86, Oxford, 1998.

Hughes, S.C., Crime, Disorder and the Risorgimento: The Politics of Policing in Bologna, Cambridge, 1994.

Hughes, S.C., Poliziotti, carabinieri, e "policemens": il bobby inglese nella polizia italiana, Le carte e la storia, 1996, 2, pp. 22-31.

James, L., The Rise and Fall of the British Empire, London, 1998.

Jensen, R.B., Liberty and Order: The Theory and Practice of Italian Public Security Policy, 1848 to the Crisis of the 1890s, New York and London, 1991.

Kennedy, P., The Rise and Fall of British Naval Mastery, London, 2001; originally 1976.

Lacaita, C., An Italian Englishman: Sir James Lacaita, London, 1933.

Laven, D., Law and Order in Habsburg Venetia 1814-1835, The Historical Journal, Summer 1996, 39, 2, pp. 383-403.

Mack Smith, D., Mazzini, New Haven \& London, 1994.

Mack Smith, D., Modern Italy: A Political History, New Haven, 1997.

Marshall, R., Massimo D'Azeglio: An Artist in Politics 1798-1866, London, 1966.

Molfese, F., Storia del brigantaggio dopo l'Unità, Milan, 1966.

O'Connor, M., The Romance of Italy and the English Imagination, Basingstoke, 1998.

Pemble, J., The Mediterranean Passion: Victorians and Edwardians in the South, Oxford, 1987.

Priestley, H.E., British Policy in the Italian Question 1866-1871, PhD thesis, University of London, 1931.

Procacci, G., (trans. Anthony Paul), History of the Italian People, London, 1970.

Riall, L., Liberal Policy and the Control of Public Order in Western Sicily 1860-1862, Historical Journal, Summer 1992, 35, 2, pp. 345-368.

Riall, L., Sicily and the Unification of Italy, 1859-1866, Oxford, 1998. 
Riall, L., Garibaldi: Invention of a Hero, New Haven, 2007.

Rizzo, D., Liberal Decorum and Men in Conflict: Rome, 1871-1890, Journal of Modern Italian Studies, Autumn 2005, 10, 3, pp. 281-296.

Rudman, H.W., Italian Nationalism and English Letters: Figures of the Risorgimento and Victorian Men of Letters, London, 1940.

St John Packe, M., The Bombs of Orsini, London, 1957.

Schram, A., Railways and the Formation of the Italian State in the Nineteenth Century, Cambridge, 1997.

Schreuder, D.M., Gladstone and Italian Unification: The Making of a Liberal , English Historical Review, Summer 1970, 85, 336, pp. 475-501.

Scott, J.C., Weapons of the Weak: Everyday Forms of Peasant Resistance, New Haven, Yale UP, 1987.

Seton-Watson, C., Italy from Liberalism to Fascism 1870-1925, London \& New York, 1969.

Southgate, D., 'The Most English Minister...' The Policies and Politics of Palmerston, London and New York, 1966.

Taylor, A.J.P., The Italian Problem in European Diplomacy 1847-1849, Manchester, 1934.

Taylor, A.J.P., The Struggle for Mastery in Europe 1848-1918, Oxford, 1971; originally 1954.

Tedeschi, M., Francia e Inghilterra di fronte alla Questione Romana 1859-60, Milan, 1978.

Thurmond Smith, P., Policing Victorian London: Political Policing, Public Order, and the London Metropolitan Police, Westport, 1985.

Todde, G., Storia di Nuoro e delle Barbagie, Cagliari, 1971.

Waterfield, G., Layard of Nineveh, London, 1963.

Wright, O.J., The Information Service : British Diplomatic and Consular Representatives in Italy (1861-70), $\mathrm{PhD}$ thesis, Lancaster University, 2005.

Wright, O.J., Sea and Sardinia: Pax Britannica versus Vendetta in the New Italy (1870), European History Quarterly, Summer 2007, 37, 3, pp. 398-416.

Wright, O.J., British Representatives and the Surveillance of Italian Affairs, 1860-1870, The Historical Journal, Summer 2008, 51, 3, pp. 669-687.

Wright, O.J., The 'Pleasantest Post' in the Service? Contrasting British Diplomatic and Consular Experiences in Early Liberal Italy, in Schaff, B. (Ed.), Exiles, Émigrés and GoBetweens : Anglo-Italian Cultural Mediation, Amsterdam and New York, 2009. 
